\title{
Subsegmental pulmonary embolism: is the emperor still naked?
}

\author{
L'embolia polmonare subsegmentaria isolata: l'imperatore \\ è ancora nudo?
}

\author{
Maurizio Zompatori ${ }^{1} \cdot$ Domenico Attinà $^{1}$ Fabio Niro ${ }^{1}$ Gualtiero Palareti ${ }^{2}$
}

\begin{abstract}
${ }^{1}$ Radiology Unit, Cardio-Thoracic-Vascular Department, University Hospital S. Orsola-Malpighi, Via Massarenti 9, 40128 Bologna, Italy ${ }^{2}$ Department of Angiology and Blood Coagulation Marino Golinelli, University Hospital S. Orsola-Malpighi, Via Massarenti 9, 40128 Bologna, Italy

Corrispondence to: D. Attinà, Tel.: +39-051-6363383, Fax: +39-051-349797, e-mail: dome.attina@gmail.com
\end{abstract}

Received: 5 September 2012 / Accepted: 25 September 2012 / Published online: 25 July 2013

(C) Springer-Verlag 2013

An ongoing clinical trial [1] evaluating the usefulness of anticoagulation therapy in patients with subsegmental pulmonary embolism (SSPE) and negative lower extremity ultrasound has newly stirred up the discussion regarding the clinical role of small peripheral pulmonary emboli (Fig. 1) [2].

Because radiology is deeply involved in this debate, we speculate that a short survey of this important matter should be of some interest to our readers.

In fact, as technology progresses, spiral computed tomography (CT) is now able to pick up very small pulmonary emboli, that radiologists could not see before. Consequently, over time, the frequency of detected pulmonary emboli has significantly increased.

The typical prevalence of the CT pulmonary angiography (CTPA) is 1 positive CT exam per 20 performed and the incidence of isolated SSPE is between 5\%-15\%, depending on the population investigated.

Until today, the treatment is substantially the same for large, central emboli and for small, peripheral SSPE. As a result, more and more people are now on blood thinners to treat very small emboli, whose clinical significance is still unknown. On the other hand, every year, 3\% of treated patients develop a major bleeding event, requiring medical care (cerebral haemorrhage, gastrointestinal bleeding or bleeding following trauma).

An increasing number of investigators don't think that treating all these small emboli in the pulmonary arteries is worth the risk of bleeding due to treatment. In other words, the point is: are all pulmonary emboli created equal? Are all of them equally concerning? Which emboli need to be treated to prevent new episodes or death?

Once upon a time, in the era before anticoagulation, only
Uno studio clinico in corso [1] sull'utilità della terapia anticoagulante nei pazienti con embolia polmonare subsegmentale (EPSS), ma senza segni di trombosi venosa all'ecografia degli arti inferiori, ha di recente riaperto il dibattito sul significato clinico dei piccoli emboli polmonari periferici (Fig. 1) [2].

Poiché la radiologia è profondamente coinvolta in questa discussione, riteniamo che una breve panoramica di questo importante argomento sia di grande interesse per i lettori.

Con il progredire della tecnologia infatti, la tomografia computerizzata (TC) spirale può ora evidenziare emboli polmonari molto piccoli, che i radiologi non hanno mai potuto osservare prima. Di conseguenza, negli ultimi anni, è notevolmente aumentata la frequenza di embolia polmonare rilevata nel corso di indagini diagnostiche.

La prevalenza di embolia polmonare (EP) nelle angio-TC polmonari (CTPA) è di un esame positivo ogni 20 eseguiti e l'incidenza di EPSS isolata è tra il 5\% ed il 15\%, a seconda della popolazione in esame.

Attualmente il trattamento dell'embolia polmonare è sostanzialmente lo stesso sia per i grandi emboli centrali sia per $i$ piccoli EPSS periferici. Di conseguenza, sempre più persone sono oggi in trattamento con anticoagulanti per emboli polmonari anche molto piccoli, il cui significato clinico è ancora da chiarire. D'altra parte, ogni anno, il 3\% dei pazienti trattati sviluppa un evento di sanguinamento maggiore, con necessità di cure mediche (emorragia cerebrale, emorragia gastrointestinale o sanguinamento a seguito di traumi).

Un crescente numero di autori non ritiene necessario il trattamento di questi piccoli emboli polmonari periferici proprio a causa dell'aumentato rischio di sanguinamento secondario al trattamento stesso. In altre parole, il punto è: 
massive emboli were found intra vitam [3] and the disease was considered nearly always fatal, with a mortality estimate ranging from $30 \%$ to $80 \%$.

The development of progressively more effective therapies and the introduction of modern imaging techniques (initially ventilation-perfusion scan, then spiral CT, that superseded scintigraphy as the most used imaging modality to assess for suspected pulmonary embolism about ten years ago) corresponded to a decrease in mortality rate to less than $3 \%$, but the therapeutic success was probably overrated, because the treated emboli changed from those detected on the basis of clinical findings (large, central) to those detected using CTPA.

The above mentioned considerations recently induced Prasad et al. [2] to state that the story of pulmonary embolism is a story of overdiagnosis. Their view was famously anticipated by a classical paper by Robin in 1977 with the evocative title: "Overdiagnosis and overtreatment of pulmonary embolism: the emperor may have no clothes" [4].

A number of radiological studies, both prospective and retrospective, assessed the prevalence of pulmonary embolism, previously unsuspected and incidentally detected on routine spiral CT exams [5-7]. Unsuspected embolism was found in $1.5 \%-3.4 \%$ of the cases, mainly in subjects over 60 years of age, with an inpatient prevalence of $4 \%$ to $5 \%$ and an outpatient prevalence of $0.6 \%$ to $2.2 \%$.

In the experience of Farrell et al. [7], 30\% of these serendipitously discovered emboli were located in the subsegmental arteries. From $70 \%$ to $83 \%$ of the patients with unsuspected emboli had cancer. Among the patients with cancer, about $10 \%$ had CT unsuspected emboli, and $30 \%$ of these emboli were not reported at the time of initial reading [7]. In another retrospective study, Gladish et al. [8] found incidental pulmonary emboli in $4 \%$ of oncology patients undergoing CT, with a higher prevalence among patients with gynaecological malignancies and those with melanoma.

Asymptomatic deep venous thrombosis (DVT) has also been reported during cancer staging. Cronin et al. [9], for example, reported a $3.3 \%$ incidence of unsuspected PE and found that incidental DVT was present in $8 \%$ of patients undergoing staging pelvic CT.

In cancer patients, the presence of unsuspected SSPE, not associated with any symptoms or clinical and laboratory specific parameters, as demonstrated by O'Connell et al. [10], has no influence on clinical conditions nor any adverse impact on survival. In all patients with SSPE who did not receive any anticoagulant therapy, the SSPE seemed resolved by the next staging CTPA scan. On the contrary, unsuspected PE involving major vessels have poorer prognosis, with a long-term mortality rate similar to that of symptomatic PE patients [11]. There remains, however, the question of whether the SSPE represents an early manifestation of hypercoagulable state, which is associated with an increased tutti gli emboli polmonari sono uguali? Possiedono tutti le stesse caratteristiche? Qual è l'embolo che necessita di essere trattato per prevenire nuovi episodi o il decesso?

Un tempo, nel periodo precedente la terapia anticoagulante, solo le embolie massive venivano scoperte in vita [3] e la malattia era considerata molto spesso fatale, con una stima della mortalità variabile dal $30 \%$ all' $80 \%$.

Lo sviluppo di terapie sempre più efficaci e l'introduzione di moderne tecniche di imaging (inizialmente la scintigrafia ventilo-perfusionale, quindi la TC spirale, che ha superato da una decina d'anni la scintigrafia come modalità di imaging più utilizzata nella valutazione della sospetta EP), hanno portato ad una riduzione del tasso di mortalità a meno del 3\%, ma il successo terapeutico è probabilmente sovrastimato poiché si è passati dal trattare solamente gli emboli rilevati sulla base dei dati clinici (emboli centrali e di grandi dimensioni), al trattare tutti gli emboli rilevati con la CTPA.

Le considerazioni suddette hanno recentemente indotto Prasad et al. [2] ad affermare che la storia dell'embolia polmonare è una storia di sovradiagnosi. La loro visione è stata notoriamente anticipata da uno storico articolo di Robin del 1977, dal titolo suggestivo: "Sovradiagnosi e sovratrattamento dell'embolia polmonare: l'imperatore potrebbe essere nudo" [4].

Numerosi studi radiologici, sia prospettici sia retrospettivi, hanno valutato la prevalenza di embolia polmonare non sospettata e rilevata incidentalmente in indagini TC di routine [5-7]. L'embolia come reperto incidentale è stata riscontrata nell' 1,5\%-3,4\% dei casi, soprattutto nei soggetti di età oltre 60 anni, con una prevalenza ospedaliera dal $4 \%$ al $5 \%$ e prevalenza ambulatoriale dallo 0,6\% al 2,2\%.

In base all'esperienza di Farrell et al. [7], il 30\% di questi emboli trovati casualmente era localizzato nelle arterie subsegmentali. Dal 70\% all'83\% dei pazienti con embolia incidentale aveva il cancro. Tra i pazienti con cancro, circa il $10 \%$ ha avuto il riscontro TC di emboli clinicamente non sospettati. Il 30\% di questi emboli non è stato segnalato al momento della prima valutazione radiologica [7]. In un altro studio retrospettivo, Gladish et al. [8] hanno trovato emboli polmonari incidentali nel 4\% degli studi TC di pazienti oncologici, con una maggiore prevalenza tra pazienti con tumori ginecologici e con melanoma.

Anche la trombosi venosa profonda (TVP) asintomatica viene spesso riscontrata durante le stadiazioni oncologiche. Cronin et al. [9], ad esempio, hanno osservato una incidenza del 3,3\% di EP non sospettata ed hanno scoperto che la TVP incidentale era presente nell'8\% dei pazienti sottoposti a stadiazione pelvica TC.

Nei pazienti con cancro, la presenza di EPSS di riscontro occasionale, non associata ad alcuna sintomatologia né a parametri clinico-laboratoristici specifici, come dimostrato da O'Connell et al. [10], non ha alcuna influenza sulle condizioni cliniche né alcun impatto sulla sopravvivenza. In tutti i pazienti con EPSS che non avevano ricevuto alcuna terapia anticoagulante, l'EPSS appariva risolta al successivo controllo CTPA. Al contrario, embolie polmonari inci- 


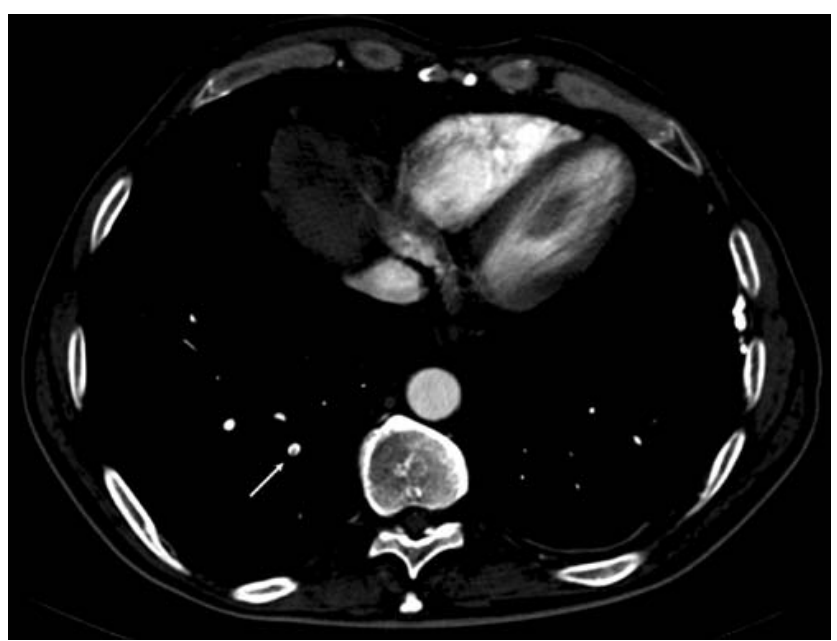

Fig. 1 Isolated right lower lobe subsegmental pulmonary embolus (arrow).

Fig. 1 Embolia polmonare subsegmentaria isolata al lobo inferiore del polmone destro (freccia).

metastatic and prothrombotic potential. Thus, despite the observations of O'Connell et al. [10], there is no shared opinion on the need for treatment of asymptomatic SSPE in cancer patients [12], even though in these patients the risk of bleeding due to anticoagulation may outweigh the risk of fatal pulmonary embolism.

SSPE are rather common even in non-cancer patients [13] and can occur in isolation, in the absence of central or larger filling defects (probably 5\% of all detected PE [2]).

In 1993 Gurney [14] asked: "if small emboli are missed at pulmonary angiography, what are the consequences for the patient?" and in 2005, Goodman [15] stated that: "it is not always clear whether small PE, in the absence of deep venous thrombosis, justify the expense, mortality and serious morbidity associated with anticoagulation".

The Fleischner Society [16] added that "the clinical relevance of small peripheral PE and the need to administer anticoagulants in such cases remain a subject of debate".

The clinical evidence was recently analysed by Wiener et al. [17], on the basis of the evaluation of an American nationwide database. According to these authors, before the introduction of CTPA, the incidence of PE was stable at 62.1 per 100,000 . The death rate decreased progressively during the last decade of the 20th century from 13.4 to 12.3 per 100,000. After the introduction of CTPA, the incidence of PE increased to 112.3 per 100,000 (81\% increase) and the mortality slightly reduced to 11.9 per 100,000 , but haemorrhagic complications due to blood thinners increased from 3.1 to 5.3 per 100,000 population ( $71 \%$ increase). Simultaneously, the diagnosis of small SSPE increased significantly [18]. The death rates remained nearly the same, whereas the incidence doubled. All in all, the introduction of CTPA dentali che coinvolgono rami maggiori hanno una prognosi peggiore, con una mortalità a lungo termine che si avvicina a quella dei pazienti con embolia sintomatica [11]. Resta comunque il dubbio se l'EPSS rappresenti una iniziale manifestazione di uno stato di ipercoagulabilità, associato ad un aumentato potenziale metastatico e protrombotico. Pertanto, nonostante le osservazioni di O'Connell et al. [10], non vi è un'opinione condivisa sulla necessità di trattamento delle EPSS asintomatiche in pazienti con cancro [12], benché in questi pazienti il rischio di sanguinamento maggiore secondario alla terapia anticoagulante possa essere superiore a quello di un'embolia polmonare.

Le EPSS sono piuttosto comuni anche nei pazienti non oncologici [13] e possono presentarsi isolatamente, in assenza di difetti di riempimento centrali o di maggiori dimensioni (probabilmente il 5\% di tutte le EP rilevate [2]).

Nel 1993 Gurney [14] si chiese: "se gli emboli di piccole dimensioni sfuggono all'angiografia polmonare, quali sono le conseguenze per il paziente?" e nel 2005 Goodman [15] aggiunse che "non è sempre chiaro se l'EP di piccole dimensioni, in assenza di trombosi venosa profonda, giustifichi il costo, la mortalità e la grave morbilità associate alla terapia anticoagulante".

La Fleischner Society [16] ha poi osservato che "la rilevanza clinica delle piccole EP periferiche e la necessità di somministrare anticoagulanti in tali casi rimangono un argomento di dibattito". L'evidenza clinica è stata recentemente analizzata da Wiener et al. [17], sulla base della valutazione di un database nordamericano. Secondo questi autori, prima dell'introduzione della CTPA, l'incidenza di EP era stabile a circa 62,1 casi ogni 100000 abitanti. Il tasso di mortalità era diminuito progressivamente durante l'ultimo decennio del XX secolo da 13,4 a 12,3 casi ogni 100000. Dopo l'introduzione della CTPA, l'incidenza di EP è aumentata a 112,3 casi ogni 100000 abitanti (aumento dell'81\%) e la mortalità si è leggermente ridotta a 11,9 casi ogni 100000, ma le complicanze emorragiche dovute ad anticoagulanti sono passate da 3,1 a 5,3 casi ogni 100000 abitanti (aumento del 71\%). Contemporaneamente, la diagnosi di piccole EPSS è aumentata significativamente [18]. Il tasso di mortalità è quindi rimasto pressoché lo stesso, mentre l'incidenza è raddoppiata. Nel complesso, l'introduzione della CTPA è stata associata con una crescente incidenza di EP e solo una minima variazione della mortalità (peraltro non significativa).

Queste osservazioni sembrano dimostrare l'esistenza di una importante quota di sovradiagnosi (ciò̀ riscontro di emboli clinicamente irrilevanti). Molti pazienti con una diagnosi di EP acuta potrebbero subire i rischi della terapia, senza trarre alcun beneficio [19]. Le conclusioni di Weiner sono state comunque criticate.

Ashrani e Heit [20] sottolinearono che nessuna prova diretta di sovradiagnosi era stata presentata da Wiener et al. [17] e che nessun dato presentato aveva dimostrato che gli eventi emorragici erano direttamente collegati alla terapia anticoagulante. Inoltre, la sequenza temporale degli eventi non poteva essere determinata esclusivamente in base ai co- 
was associated with a rising incidence of PE and a minimal change in mortality (not significant).

These observations seem to demonstrate the existence of a significant component of overdiagnosis (i.e., finding clinically unimportant emboli). A lot of patients with a diagnosis of acute PE may suffer the risks of therapy without any benefit [19]. Wiener et al.'s [17] conclusions, however, were very soon criticised.

Ashrani and Heit [20] pointed out that no direct evidence of overdiagnosis had been presented by Wiener et al. [17] nor any data showing that hemorrhagic events were directly related to anticoagulation. Moreover, the temporal sequence of events could not be determined from discharge diagnosis codes. For example, a person with discharge diagnosis codes for PE and intracranial haemorrhage could have been admitted with primary intracranial bleeding and developed a PE as a complication of the hospitalisation.

Nevertheless, evidence that overdiagnosis represents a real problem continued to increase.

In a retrospective review of their experience, Suh et al. [21] reported on the prevalence of PE, lower extremity DVT and anticoagulation therapy of 50 patients, selected from 1273 consecutive CTPAs performed over a 6-month period. The authors clearly demonstrated that there is a wide spectrum of embolic disease ("dots" and "clots", in their words). Of the 50 patients with positive CTPA, 17 (34\%) had "dots", i.e. small peripheral SSPE and a minimal clot burden, without any sign of DVT. The large majority of them $(88 \%)$ received anticoagulation. The authors concluded that we need further studies to determine the significance of such "dots", considering the risk of anticoagulation, because the risk can outweigh the benefits.

Another problem not easy to resolve is the high CTPA interobserver variability for SSPE diagnosis with CTPA, which is greatly influenced by the level of experience of the radiologist [22]. Perrier et al. [23] in a study involving radiologists with different experience showed that $11 \%$ of CTPAs with an initial diagnosis of SSPE, re-interpreted by a highly experienced thoracic radiologist, were later proved negative. Therefore, many of the SSPE diagnosed with CTPA may be actually false positive results, due to a misinterpretation of the operator, to motion artefacts or to poor opacification of the vessel. In this regard, Carrier et al. [24] state that all CTPA scans positive for isolated SSPE should be reviewed by an experienced thoracic radiologist as a "second opinion".

Besides, not only the presence but also the number, size and position of the emboli and the whole clinical scenario should be taken into due consideration.

In some cases, isolated SSPE without DVT could be even considered a para-physiological, incidental finding, to be left alone.

Goodman [15] noted that a normal function of the pul- dici delle diagnosi di dimissione. Ad esempio, una persona con codici di dimissione per diagnosi di EP ed emorragia intracranica avrebbe potuto essere stata ricoverata per una iniziale emorragia intracranica ed aver sviluppato successivamente una EP come complicanza durante il ricovero.

Tuttavia, l'evidenza che la sovradiagnosi rappresenti un problema reale continua a crescere.

In una revisione retrospettiva della loro esperienza, Suh et al. [21] hanno riportato la prevalenza di EP, TVP degli arti inferiori e terapia anticoagulante di 50 pazienti, selezionati tra 1273 CTPA consecutive eseguite nel corso di un periodo di 6 mesi. Gli autori hanno chiaramente dimostrato che vi è un ampio spettro di patologie emboliche (da loro definite "dots" e "clots"). Dei 50 pazienti con CTPA positiva, 17 (34\%) avevano "dots", cioè piccole e periferiche EPSS, con un'estensione del coagulo minimale e senza alcun segno di TVP. La grande maggioranza di essi (88\%) era stata trattata comunque con terapia anticoagulante. Gli autori hanno concluso che sono necessari ulteriori studi per determinare l'importanza di tali "dots", considerando il rischio della terapia anticoagulante, poiché $i$ rischi possono superare $i$ benefici.

Un altro problema di non facile soluzione è quello dell'elevata variabilità interosservatore nella diagnosi di EPSS alla CTPA, che è notevolmente influenzata dal livello di esperienza del radiologo [22]. Perrier et al. [23] in uno studio che coinvolgeva radiologi con diversa esperienza, hanno evidenziato che l'11\% delle CTPA con diagnosi iniziale di EPSS, reinterpretate da un radiologo toracico con elevata esperienza, si sono poi rivelate negative. Pertanto, molte delle EPSS diagnosticate alla CTPA potrebbero essere in realtà dei falsi positivi dovuti ad un errore di interpretazione dell'operatore, ad artefatti da movimento o a scarsa opacizzazione del vaso. A tal proposito Carrier et al. [24] affermano che tutte le CTPA positive per EPSS isolata dovrebbero essere reinterpretate da un radiologo toracico esperto, sotto forma di consulto interno o second opinion.

Inoltre, non solo la presenza, ma anche il numero, la dimensione e la posizione degli emboli, oltre all'intero scenario clinico, dovrebbero essere presi in debita considerazione.

In alcuni casi, EPSS isolate, senza TVP, potrebbero essere considerate reperti incidentali parafisiologici e non essere trattate.

Goodman [15] ha osservato infatti che una normale funzione del letto capillare polmonare è quella di filtrare piccoli grumi di sangue per proteggere la circolazione sistemica. Perciò, come possiamo determinare quali pazienti con piccole EP dovrebbero essere trattati?

Tapson [25] ha suggerito che in questi casi lo studio degli arti inferiori potrebbe probabilmente essere utile. Un trombo residuo nelle vene delle gambe potrebbe identificare $i \mathrm{pa}$ zienti a più alto rischio di recidive. Questo autore ha riconosciuto che la sovradiagnosi di EP è un fenomeno reale, ma ha dichiarato che è probabile che un sottogruppo di pazienti con EP incidentale tragga comunque beneficio dalla terapia.

$L ' E P$ acuta potrebbe essere in realtà un fenomeno sia so- 
monary capillary bed is to filter small clots to protect the systemic circulation. So, how do we determine which patients with small PE should be treated?

Tapson [25] suggested that examining the legs would likely be useful in these cases. A residual clot in the legs might identify the highest risk patients for recurrences. This author acknowledged that overdiagnosis of PE is a real phenomenon, but stated that it is likely that a subset of patients with incidental PE benefits from therapy.

Acute PE may well be both over- and underdiagnosed, because most patients who die from acute PE are still not suspected until death.

Sheh et al. [26] evaluated retrospectively 2087 patients with pulmonary embolism. In their experience, from 2000 to 2007 the incidence of PE increased from 0.69 to 0.91 per 100 admissions, in strong correlation with increased use of CTPA. There was no change in mortality, but the casefatality rate decreased from $5.7 \%$ to $3.3 \%$.

On average, emboli detected with CTPA were one half as lethal as those diagnosed with scintigraphy. The authors concluded that the shift in imaging from scintigraphy to CTPA resulted in increased diagnosis of a less fatal spectrum of emboli, raising the possibility of over diagnosis.

Of course, these conclusions don't take into consideration other important factors, such as the CT capability to offer an alternative diagnosis in patients with acute chest pain (e.g., aortic dissection), which clearly is not in the realm of scintigraphy. A retrospective study revealed that CTPA, performed for a clinical suspicion of acute PE, showed other clinically relevant findings, requiring immediate and specific intervention, in $27.5 \%$ of cases [27].

The CT radiation exposure is progressively reduced but it is still higher than that of scintigraphy. A risk-benefit analysis was performed in a retrospective review of 1424 consecutive CTPA by Woo et al. [28]. Benefit-to-risk ratios were calculated by dividing the mortality benefit of preventing a fatal PE by the risk of radiation-induced cancer from the CT scan. The authors detected PE in $13.2 \%$ of patients. Both inpatients and emergency department patients had significantly higher rates of PE than outpatients (respectively $14 \%$ and $14.5 \%$ versus $6.8 \%$ ). Males received significantly a higher dose than females (9.7 versus $8.4 \mathrm{mSv}$ ) but males had a significantly lower lifetime attributable risk of cancer mortality than females. Ambulatory women had the highest benefit-to-risk ratio. Of course, the benefit-to-risk ratio could be and probably will be decreased very soon by further optimising the radiation dose delivery, due to technology evolution. Woo et al. concluded that, depending on multiple factors such as patient demographics and radiation dose, the benefits of using CTPA for suspected PE range from 25 to 187 times the risks.

Besides, the risks of diagnosing and treating PE must be compared to the risks of missed diagnosis and non-treat- vra- che sotto-diagnosticato, poiché molti pazienti che mиoiono a causa di un'embolia acuta non ricevono la diagnosi corretta intra vitam.

Sheh et al. [26] hanno valutato retrospettivamente 2087 casi di pazienti con embolia polmonare. Nella loro esperienza, dal 2000 al 2007, l'incidenza di EP è aumentata da 0,69 a 0,91 casi ogni 100 ricoveri, in forte correlazione con l'utilizzo maggiore della CTPA. Non vi è stato alcun cambiamento nella mortalità, ma il tasso di casi fatali è diminuito dal $5,7 \%$ al $3,3 \%$.

In media, gli emboli letali rilevati con la CTPA erano la metà di quelli diagnosticati con la scintigrafia. Gli autori hanno concluso che il passaggio nel campo dell'imaging dalla scintigrafia alla CTPA ha portato ad un aumento di diagnosi di uno spettro meno fatale di emboli, aumentando così la possibilità di sovradiagnosi.

Ovviamente, queste conclusioni non tengono in considerazione altri fattori importanti, come la capacità della TC di offrire una diagnosi alternativa nei pazienti con dolore toracico acuto (es.: dissezione aortica), che chiaramente non è ottenibile con la scintigrafia. Uno studio retrospettivo ha dimostrato che la CTPA eseguita in pazienti con sospetta EP acuta, nel $27.5 \%$ dei casi evidenziava altri reperti clinicamente rilevanti che necessitavano di un intervento immediato e specifico [27].

L'esposizione a radiazioni della TC si è progressivamente ridotta, ma è ancora superiore a quella della scintigrafia. Un'analisi rischio-beneficio è stata effettuata in una revisione retrospettiva di 1424 CTPA consecutive da Woo et al. [28]. Il rapporto rischio-beneficio è stato calcolato dividendo il beneficio sulla mortalità dato dalla possibilità di prevenire un EP fatale con il rischio di cancro indotto dalle radiazioni della scansione TC. Gli autori hanno rilevato EP nel 13,2\% dei pazienti. Sia i pazienti ricoverati che i pazienti del Pronto Soccorso hanno mostrato tassi significativamente più elevati di EP rispetto a pazienti ambulatoriali (rispettivamente $14 \%$ e $14,5 \%$ versus $6,8 \%$ ). Gli uomini hanno ricevuto una dose di radiazioni significativamente superiore rispetto alle donne (9,7 vs 8,4 mSv), ma gli uomini hanno un'aspettativa di vita significativamente più bassa rispetto alle donne, con ridotta mortalità per cancro attribuibile alle radiazioni. Le pazienti donne ambulatoriali sono quelle che hanno avuto un rapporto rischio-beneficio più alto. Naturalmente, il rapporto rischio-beneficio potrebbe essere, e probabilmente sarà, ulteriormente abbassato molto presto, per l'ottimizzazione della dose di radiazioni, grazie all'evoluzione tecnologica. Woo et al. [28] hanno concluso che, a seconda di molteplici fattori, quali dati anagrafici del paziente e la dose di radiazioni erogata, i benefici dell'utilizzo della CTPA per sospetta EP variano da 25 a 187 volte i rischi.

Inoltre, $i$ rischi secondari alla diagnosi ed al trattamento dell'EP devono essere confrontati con il rischio della mancata diagnosi e del non-trattamento. Questi rischi sono certamente difficili da stimare, in quanto dipendono da molteplici fattori, variano da caso a caso e dovrebbero essere valutati su base individuale [29, 30]. 
ment. These risks are certainly difficult to estimate, as they depend on multiple factors, but they vary by case and should be evaluated on an individual basis [29, 30].

In the meantime, Stein et al. [31] suggested withholding treatment of SSPE, after fully informing patients, provided that (a) pulmonary reserve is good; (b) there is no evidence of DVT on serial testing; (c) major risk factors for PE are no longer present; (d) there is no history of central venous catheterisation or atrial fibrillation; (e) there is a willingness to return for serial venous ultrasound.

Under these conditions, patients diagnosed with isolated SSPE have favourable 3-month outcomes with a recurrence rate $<1 \%$ and no PE-attributed deaths. D-dimer testing is also less sensitive for SSPE versus segmental or larger emboli (76\% sensitivity versus $98 \%$ ) [32]; this implies that many symptomatic patients with a negative $\mathrm{D}$-dimer result may actually be affected from isolated SSPE. These conclusions were confirmed in a review of 93 patients with isolated SSPE and no DVT, selected from 10.453 consecutive studies by Donato et al. [33]. Given that the combination of a negative D-dimer result and a non-high pre-test probability can, with reasonable safety, exclude a major PE without the use of CTPA, a greater use of these diagnostic algorithms is likely going to reduce the overdiagnosis of SSPE.

Considering the absence of prospective data demonstrating the benefits of treating SSPE and the risks associated with anticoagulant therapy, the results of the ongoing clinical trial [1] are expected in the scientific community to determine if and how patients with symptomatic SSPE should be treated.

Another potential future direction of research could be the proposal of a model of multiparametric "scoring" for symptomatic isolated SSPE based on the integration of the CTPA results with other clinical and laboratory parameters (D-dimer, Doppler lower limbs, $\mathrm{PaO}_{2}$, signs of right heart overload on echocardiography) in order to identify the categories of patients who can really benefit from a specific therapy.

In conclusion, the availability of modern CTPA obviously simplifies the diagnosis but it creates new, previously unknown problems. The need for further information is obvious, because multiple questions regarding acute $\mathrm{PE}$ and particularly isolated SSPE are still unanswered.

Single-photon emission computed tomography (SPECT), ventilation-perfusion scintigraphy and magnetic resonance (MR) may play a major role in the near future but the diagnosis of SSPE requires a very high spatial resolution and probably will remain a CT diagnosis.

Besides, based on Prospective Investigation of Pulmonary Embolism Diagnosis (PIOPED) II data (sensitivity $83 \%$, specificity 96\%) [34], at a disease prevalence of approximately $5 \%$, the number of false positive patients approaches the number of true positive CTPA studies for the detection of acute $\mathrm{PE}$, and this problem is probably even
Nel frattempo, Stein et al. [31] hanno suggerito di sospendere il trattamento in caso di EPSS, dopo aver pienamente informato i pazienti, nel caso in cui sussistano: (a) una buona riserva funzionale polmonare; (b) nessuna evidenza di TVP nelle indagini di controllo; (c) nessun fattore di rischio maggiore per EP; (d) non storia di cateterismo venoso centrale o di fibrillazione atriale; (e) disponibilità del paziente a ritornare per un controllo mediante ecografia venosa.

In queste condizioni, i pazienti con diagnosi di EPSS isolata hanno un outcome favorevole a 3 mesi, con un tasso di recidiva $<1 \%$ e assenza di decessi attribuibili alla EP. Anche il test del D-dimero è meno sensibile per l'EPSS rispetto alle embolie segmentarie o maggiori $(76 \%$ di sensibilità rispetto al 98\%) [32]; ciò implica che un certo numero di pazienti sintomatici ma con D-dimero negativo potrebbero in realtà essere affetti da EPSS isolata. Queste conclusioni sono state confermate in una revisione di 93 pazienti con EPSS isolata e senza TVP, selezionati tra 10453 studi consecutivi da Donato et al. [33]. Dal momento che la combinazione di un test del D-dimero negativo e una probabilità pre-test non alta possono con ragionevole sicurezza escludere una EP maggiore senza ricorrere alla CTPA, un maggiore utilizzo di questi algoritmi diagnostici è auspicabile per ridurre la sovradiagnosi di EPSS.

Considerando l'assenza di dati prospettici che dimostrino $i$ benefici del trattamento delle EPSS ed i rischi legati alla terapia anticoagulante, i risultati dello studio in corso [1] sono attesi della comunità scientifica, per determinare se e come i pazienti con EPSS sintomatica debbano essere trattati.

Un'altra possibile futura direzione della ricerca potrebbe essere quella di proporre un modello di scoring multiparametrico per le EPSS sintomatiche isolate che preveda l'integrazione del dato CTPA con altri dati clinico-laboratoristici (D-dimero, eco-Doppler arti inferiori, $\mathrm{PaO}_{2}$, segni di sovraccarico del cuore destro all'ecocardiografia) allo scopo di individuare le categorie di pazienti che possano realmente beneficiare di una terapia specifica.

In conclusione, la disponibilità della moderna CTPA, ovviamente, semplifica la diagnosi, ma crea nuovi problemi, in precedenza sconosciuti. La necessità di ulteriori informazioni è ovvia, perché molte domande relative all'EP acuta e in particolare all'EPSS isolata risultano ancora senza risposta.

La single-photon emission computed tomography (SPECT), la scintigrafia ventilo-perfusionale e la risonanza magnetica (RM) possono giocare un ruolo importante nel prossimo futuro, ma la diagnosi di EPSS richiede una risoluzione spaziale molto alta e probabilmente rimarrà una diagnosi esclusiva della TC.

Inoltre, sulla base dei dati dello studio Prospective Investigation of Pulmonary Embolism Diagnosis (PIOPED) II (83\% sensibilità, specificità 96\%) [34], con una prevalenza di malattia di circa il 5\%, il numero degli studi CTPA per il rilevamento di EP acuta che risultano falsi positivi si avvicina molto a quello dei veri positivi e questo problema è probabilmente ancora più importante in caso di EPSS. I 
more important in case of SSPE. Patients with false positive results may receive unnecessary and potentially harmful treatment.

As pointed out by Cronin and Kelly [35], the prevalence of disease, along with the diagnostic accuracy of CTPA, must be taken into account in the evaluation of this problem in a Bayesian scenario.

Prasad et al. [2] at the end of their article, rightly stated that "PE captures all the complexity of medicine in the evidence-based era".

They argue (and we agree) that outcome-based clinical trials with long-term follow-up would be helpful to further guide management but "trial funding should move away from industry-sponsored studies, which continue to test triviality", alluding to the raging debate regarding the so called "disease mongering" [36], one of the greatest problems of the modern medicine.

But that is another story. pazienti che risultano falsi positivi possono quindi ricevere un trattamento inutile e potenzialmente dannoso.

Come sottolineato da Cronin e Kelly [35], la prevalenza di malattia, insieme con l'accuratezza diagnostica della CTPA, devono essere presi in considerazione nella valutazione di questo problema in un'ottica bayesiana.

Prasad et al. [2] alla fine del loro articolo correttamente affermano che "l'EP racchiude in sé tutta la complessità dell'attuale medicina basata sull'evidenza".

Essi sostengono (e noi siamo d'accordo) che ulteriori sperimentazioni cliniche basate su risultati con follow-up a lungo termine sarebbero utili come ulteriore guida al management, ma "il finanziamento di questi studi non dovrebbe essere sponsorizzato dalle industrie, che continuano solo a dimostrare banalità", alludendo al dibattito che infuria in merito alla cosiddetta "mercificazione della malattia" [36], il disease mongering, uno dei maggiori problemi della medicina moderna.

Ma questa è un'altra storia.

Conflict of interest None of the authors has any actual or potential conflict of interest including financial, personal or other relationships with other people or organisations that could inappropriately influence this work.

\section{References/Bibliografia}

1. Carrier M (2011) A study to evaluate the safety of withholding anticoagulation in patients with subsegmental PE who have a negative serial bilateral lower extremity ultrasound (SSPE). http:clinicaltrials. gov/ct2/show/NCT01455818. Last access May 2013

2. Prasad V, Rho J, Cifu A (2012) The diagnosis and treatment of pulmonary embolism. Arch Intern Med 172:955958

3. Rubinstein I, Murray D, Hoffstein V (1988) Fatal pulmonary emboli in hospitalized patients. An autopsy study. Arch Intern Med 148:1425-1426

4. Robin ED (1977) Overdiagnosis and overtreatment of pulmonary embolism: the emperor may have no clothes. Ann Intern Med 87:775-781

5. Storto ML, Di Credico A, Guido F et al (2005) Incidental detection of pulmonary emboli on routine MDCT of the chest. AJR Am J Roentgenol184:264-267

6. Gosselin MV, Rubin GD, Leung AN et al (1998) Unsuspected pulmonary embolism: prospective detection on routine helical CT scans. Radiology 208:209-215
7. Farrell C, Jones M, Girvin F et al (2010) Unsuspected pulmonary embolism identified using multidetector computed tomography in hospital outpatients. Clin Radiol 65:1-5

8. Gladish GW, Choe DH, Marom EM et al (2006) Incidental pulmonary emboli in oncology patients: prevalence, CT evaluation, and natural history. Radiology 240:246-255

9. Cronin CG, Lohan DG, Keane M et al (2007) Prevalence and significance of asymptomatic venous thromboembolic disease found on oncologic staging CT. AJR Am J Roentgenol 189:162-170

10. O'Connell C, Razavi P, Ghalichi M, et al (2011) Unsuspected pulmonary emboli adversely impact survival in patients with cancer undergoing routine staging multi-row detector computed tomography scanning. J Thromb Haemost 9:305-311

11. Piatek C, O’Connell C (2012) Unsuspected pulmonary embolism: impact on mortality among cancer patients. Curr Opin Pulm Med 18:406409

12. den Exter PL, Jimènez D, Kroft LJ et al (2012) Outcome of incidentally diagnosed pulmonary embolism in patients with malignancy. Curr Opin Pulm Med 18:399-405
13. Stein PD, Fowler SE, Goodman LR et al (2006) Multidetector computed tomography for acute pulmonary embolism. N Engl J Med 354:23172327

14. Gurney JW (1993) No fooling around: direct visualization of pulmonary embolism. Radiology 188:618-619

15. Goodman LR (2005) Small pulmonary emboli. What do we know? Radiology 234:654-658

16. Remy-Jardin M, Pistolesi M, Goodman LR et al (2007) Management of suspected acute pulmonary embolism in the era of CT angiography: a statement from the Fleischner Society. Radiology 245:315-329

17. Wiener RS, Schwartz LM, Woloshin S (2011) Time trends in pulmonary embolism in the United States: evidence of overdiagnosis. Arch Intern Med 171:831-837

18. Schoepf UJ, Holzknecht N, Helmberger TK et al (2002) Subsegmental pulmonary emboli: improved detection with thin-collimation multi-detector row spiral CT. Radiology 222:483-490

19. Linkins LA, Choi PT, Douketis JD (2003) Clinical impact of bleeding in patients taking oral anticoagulant therapy for venous thromboembolism: a meta-analysis. Ann Intern Med 139:893-900 
20. Ashrani A, Heit J (2011) Caution on interpreting the time trends in pulmonary embolism as "overdiagnosis" Arch Intern Med 171:1963-1964

21. Suh JM, Cronan JJ, Healey TT (2010) Dots are not clots: the over-diagnosis and over-treatment of PE. Emerg Radiol 17:347-352

22. Perrier A, Bounameaux H, Morabia A et al (1996) Diagnosis of pulmonary embolism by a decision analysis-based strategy including clinical probability, D-dimer levels, and ultrasonography: a management study. Arch Intern Med 156:531-536

23. Perrier A, Desmarais S, Miron MJ et al (1999) Non-invasive diagnosis of venous thromboembolism in outpatients. Lancet 353:190-195

24. Carrier M, Righini M, Le Gal G (2012) Symptomatic subsegmental pulmonary embolism: what is the next step? J Thromb Haemost 10:1486-1490

25. Tapson V (2011) Acute pulmonary embolism: comment on "time trends in pulmonary embolism in the United States". Arch Intern Med 171:837-839
26. Sheh SH, Bellin E, Freeman KD et al (2012) Pulmonary embolism diagnosis and mortality with pulmonary $\mathrm{CT}$ angiography versus ventilationperfusion scintigraphy: evidence of overdiagnosis with CT? AJR Am J Roentgenol 198:1340-1345

27. Cereser L, Bagatto D, Girometti R, et al (2011) Chest multidetector computed tomography (MDCT) in patients with suspected acute pulmonary embolism: diagnostic yield and proportion of other clinically relevant findings. Radiol Med 116:219-229

28. Woo JK, Chiu RY, Thakur Y et al (2012) Risk-benefit analysis of pulmonary CT angiography in patients with suspected pulmonary embolus. AJR Am J Roentgenol 198:1332-1339

29. Araoz PA, Haramati LB, Mayo JR et al (2012) Panel discussion: pulmonary embolism imaging and outcomes. AJR Am J Roentgenol 198:1313-1319

30. Riopel C, Righini M (2011) Should we treat subsegmental pulmonary embolism? J Mal Vasc 36:37-41

31. Stein PD, Goodman LR, Hull RD et al (2012) Diagnosis and management of isolated subsegmental pulmonary embolism. Review and assessment of options. Clin Appl Thromb Hemost 18:20-26
32. Sijens PE, van Ingen HE, van Beek EJ et al (2000) Rapid ELISA assay for plasma D-Dimer in the diagnosis of segmental and subsegmental pulmonary embolism: a comparison with pulmonary angiography. Thromb Haemost 84:156-159

33. Donato AA, Khoche S, Santora J et al (2010) Clinical outcomes in patients with isolated subsegmental pulmonary emboli diagnosed by multidetector CT pulmonary angiography. Thromb Res 126:e266-e270

34. Stein PD, Woodard PK, Weg JG et al (2007) Diagnostic pathways in acute pulmonary embolism: recommendations of the PIOPED II Investigators. Radiology 242:15-21

35. Cronin P, Kelly AM (2011) Influence of populazion prevalences on numbers of false positives: an overlooked entity. Acad Radiol 18:1087-1093

36. Moynihan R Henry D (2006) The fight against disease mongering. Generating knowledge for action. PLoS Med 3:e191 